\title{
Article
}

\section{Antecedents and outcomes of consumer environmentally friendly attitudes and behaviour}

Leonidou, Leonidas C., Leonidou, Constantinos N. and Kvasova, Olga

Available at http://clok.uclan.ac.uk/7084/

Leonidou, Leonidas C., Leonidou, Constantinos N. and Kvasova, Olga (2010) Antecedents and outcomes of consumer environmentally friendly attitudes and behaviour. Journal of Marketing Management, 26 (13-14). pp. 1319-1344. ISSN 0267-257X

It is advisable to refer to the publisher's version if you intend to cite from the work. http://dx.doi.org/10.1080/0267257X.2010.523710

For more information about UCLan's research in this area go to http://www.uclan.ac.uk/researchgroups/ and search for < name of research Group>.

For information about Research generally at UCLan please go to http://www.uclan.ac.uk/research/

All outputs in CLoK are protected by Intellectual Property Rights law, including Copyright law. Copyright, IPR and Moral Rights for the works on this site are retained by the individual authors and/or other copyright owners. Terms and conditions for use of this material are defined in the policies page.

\section{CLoK}

Central Lancashire online Knowledge www.clok.uclan.ac.uk

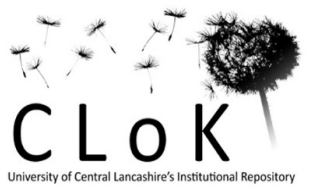




\title{
Antecedents and outcomes of consumer environmentally-friendly attitudes and behaviour
}

\author{
by \\ Dr Leonidas C. Leonidou \\ Professor of Marketing \\ University of Cyprus \\ Dr Constantinos N. Leonidou \\ Lecturer in Marketing \\ University of Leeds \\ Ms. Olga Kvasova \\ PhD Candidate \\ Lulea University of Technology \\ Journal of Marketing Management \\ (Special Issue of the Academy of Marketing Conference) \\ Submitted 21-7-2010; Revised 04-09-2010
}

\section{Acknowledgements}

The authors would like to thank the Special Issue Editor and the anonymous Reviewers of the Journal for their valuable insights and constructive comments on previous versions of the article. They also acknowledge Pantelis Gregori and Christina Pelidou for their assistance in collecting the data for the purposes of this study. 


\title{
Antecedents and outcomes of consumer environmentally-friendly attitudes and behaviour
}

\begin{abstract}
With the intensification of problems relating to the environment, a growing number of consumers are becoming more ecologically conscious in their preferences and purchases of goods. This paper presents the results of a study conducted among 500 Cypriot consumers, focusing on the factors that shape consumer environmental attitudes and behaviour, as well as on the resulting outcomes. The findings confirmed that both the inward and outward environmental attitudes of a consumer are positively influenced by his/her degree of collectivism, long-term orientation, political involvement, deontology, and law obedience, but have no connection with liberalism. The adoption of an inward environmental attitude was also found to be conducive to green purchasing behaviour that ultimately leads to high product satisfaction. On the other hand, an outward environmental attitude facilitates the adoption of a general environmental behaviour, which is responsible for greater satisfaction with life. The findings of the study have important implications for shaping effective company offerings to consumers in target markets, as well as formulating appropriate policies at the governmental level to enhance environmental sensitivity among citizens.
\end{abstract}

\section{Keywords}

Environmental marketing; Consumer behaviour; Buyer satisfaction. 


\section{Introduction}

The emergence of ecologically-conscious consumers was first noted in the late 1960s and early 1970s, as a response to the appearance of worrying signs (e.g., land degradation, animal extinction, atmospheric pollution) concerning the systematic maltreatment of the environment (Fisk, 1973; Kinnear, Taylor, \& Ahmed 1974). Throughout the late 1970s and 1980s green issues were not at the forefront of consumer concerns, mainly due to better economic prosperity, spiralling oil prices, and tightening pollution control (Schlegelmilch, Bohlen, \& Diamantopoulos, 1996). However, with the emergence of a new set of environmental problems in the 1990s (e.g., global warming, ozone hole, Exxon Valdez case), consumers began to seek environmentallyfriendly alternatives in their purchases. In the 2000s, the ecological sensitivity of consumers has skyrocketed, reflecting increasing public concern to halt, and even reverse, the negative effect of the human factor on the environment.

In recent years, consumer interest in ecological issues has dramatically increased as demonstrated by an increasing: (a) involvement in environmental-caring activities, such as recycling packaging, energy saving, and composting foods; (b) acceptance of lower technical performance of the products purchased in exchange for better eco-performance; (c) reliance of purchasing decisions on environmental-related issues, such as biodegradable, CFC-free, and organically grown products; (d) willingness to pay higher prices for acquiring environmentallyfriendly goods; and (e) tendency to travel to non-traditional distribution outlets, such as organic food sellers, to purchase green products (Mostafa, 2007). This change in the ecological behaviour of consumers has been driven by various factors, including wider media coverage, more stringent legislation, and greater involvement of environmental pressure groups (Aitken, 2006; Melillo \& Miller, 2006). 
Although at times organisations have primarily been accused of being responsible for causing environmental problems through, for example, the use of inappropriate equipment, dangerous substances, and non-recyclable materials, consumers have also been blamed for their uncontrollable consumption of goods and irresponsible treatment of the environment (Menon \& Menon, 1997; Banerjee, 2002). Thus, on the one hand, understanding the motives, attitudes, behaviour, and actions of consumers with regard to ecological issues is of paramount importance in alleviating part of the problems associated with the environment (Roberts \& Bacon, 1997). On the other hand, a deeper understanding of the characteristics of green consumers by organisations can lead to the design of more efficient and effective sustainability marketing programs (RundleThiele, Paladino, \& Apostol, 2008). However, there is still no clear consensus in the extant literature regarding the forces motivating environmental concern among consumers, especially as regards cultural (e.g., McCarty \& Shrum, 2001), societal (e.g., Roberts, 1996), and ethical (e.g., Chan, Wong, \& Leung, 2008) factors. There is also inadequate understanding about the consumer eco-friendly attitude-behaviour link (Diamantopoulos, Schlegelmilch, Sinkovics, \& Bohlen, 2003), while the literature has treated the measurement of environmental attitudes and behaviour in a composite manner (Fransson \& Garling, 1999; Kilbourne \& Pickett, 2008; Sarigöllü, 2009).

This article aims to fill these gaps in the green marketing literature by taking a fresh look at the antecedents and outcomes of consumer environmentally-friendly attitudes and behaviour. Specifically, it has three major objectives: (a) to understand the role of certain key motivations derived from cultural, political, and ethical sources in the development of inward and outward environmentally-friendly attitudes by consumers; (b) to investigate the link between this inward and outward environmental attitudes and consumer environmental behaviour (whether purchasing 
or general); and (c) to examine the effect of purchasing and general environmental behaviour on consumers' product satisfaction and life satisfaction respectively.

The remainder of the article is organised into seven parts. In the following section, we review the pertinent literature and assess its major streams. We then present the conceptual framework of the study and formulate the research hypotheses. In the subsequent section, the investigation method adopted is explained. This is followed by an analysis of the results and the testing of the hypotheses. In the final sections, conclusions and implications are derived from the study findings, and suggestions for future research are provided.

\section{Previous research}

Research on environmentally-conscious consumers has grown exponentially over the last four decades, with dozens of studies conducted on the subject until now. This research followed four major streams which are explained below.

The first research stream deals with macro-marketing issues relating to green consumer attitudes and behaviour. By particularly focusing on aspects such as the dominant social paradigm of Western industrial societies (Kilbourne, Beckmann, \& Thelen, 2002), individuals' materialistic and ecological values (Kilbourne \& Pickett, 2008), and consumerism (Barksdale \& Darden, 1972), the emphasis is on the role of macro environment (e.g., technological, political, economical) in influencing society's values and beliefs (Stern, Dietz, \& Guagnano, 1995). These in turn are considered important in shaping environmental attitudes, forming behavioural intentions, and affecting consumer actions (Kilbourne \& Beckmann, 1998). Ultimately, adopting a sustainable consumption perspective cannot only minimize environmental effects for current and future generations, but can also produce a better quality of life (Kilbourne, McDonagh, \& 
Prothero, 1997). The thrust of this research is on both the quality and quantity of consumption in Western industrial societies, which are considered to be one of the causes of environmental problems. As such, their examination is critical for understanding the changes in environmental stability and sustainability (Porritt, 1984; Jones, 1987). While previously the role of consumption was investigated in relation to the environment per se, research in this area attempts to uncover the macro-caveats leading to ecologically-friendly consumption lifestyles. Several studies (e.g., Roberts \& Bacon, 1997; Mostafa, 2007) used the Natural Environmental Paradigm (NEP) scale, originally developed by Dunlap and Van Liere (1978), to investigate whether a more general position about society and the environment could have an impact on environmentally-conscious consumer behaviour.

The second stream of studies focuses on micro-marketing issues relating to consumer interest, literacy, and awareness of ecological problems. Scholars in this area sought to define and describe the nature of green consumers, while at the same time investigating the nature of green consumer segments using different variables and classifications (Kilbourne \& Beckmann, 1998). Specifically, the emphasis was on operationalising, conceptualising, and measuring consumers' environmental attitudes and behaviour (Bohlen, Schlegelmilch, \& Diamantopoulos, 1993; Roberts, 1996). It also focused on assessing the role of demographic, social, and other factors in segmenting the market and sketching the profile of green consumers (see, for example, Anderson et al., 1974; Pickett et al., 1993; Diamantopoulos et al., 2003). The use of traditional socio-demographic factors, even though important, was characterized as inappropriate for identifying green consumers because of contradicting and inconclusive findings (Kinnear et al., 1974; Peattie 2001; Diamantopoulos et al., 2003). For instance, while Levin (1990) found that consumers with better education and higher income are more environmentally sensitive, the 
opposite was revealed in Roberts' (1996) study. Moreover, while Van Liere and Dunlap (1981) and Laroche et al. (2001) identified a positive association between gender type and ecological concern, Arcury, Scollay and Johnson (1987) reported a negative one. Furthermore, in a study conducted by Diamantopoulos et al. (2003) no link was established between the sociodemographic consumer characteristics (e.g., gender, age, income) and pro-environmental actions.

The third research stream concentrates on psychological, cultural, societal, and other parameters acting as predictors of consumer ecological concern. Some of the measures employed were: personal values, such as security, fun/enjoyment, and self-gratification (e.g., McCarty \& Shrum, 1994; Jansson, Marell, \& Nordlund, 2010); ethical ideologies, such as deontologism and teleologism (e.g., Spash, 1997; Chan et al., 2008); societal factors, such as liberalism and social altruism (e.g., Straughan \& Roberts, 1999; Paladino, 2005); cultural orientations, such as collectivism and individualism (e.g., Laroche, Bergeron, \& Barbaro-Forleo, 1999; McCarty \& Shrum, 2001); and personal environmental beliefs, such as faith in others, perceived consumer effectiveness, and susceptibility to normative influence (e.g., Ellen et al,. 1991; Minton \& Rose, 1997; Smith \& Paladino, 2010). Although these parameters provided very useful insights in explaining ecologically friendly behaviour, they were often criticized as being difficult to measure and implement (Brooker, 1976; Balderjahn, 1988; Chan, 1999; Kilbourne \& Pickett, 2008).

The final stream of studies deals with the relationship between environmentally-friendly consumer attitudes and environmentally-friendly behaviour. Specifically, researchers in the area examined attitudes and behavioural intentions towards energy conservation (Heslop et al., 1981; Paladino \& Baggiere, 2008), recycling (McCarty \& Shrum, 2001), environmental activism (Kilbourne \& Pickett, 2008), eco-conscious product purchasing (Schlegelmilch et al., 1996), and 
willingness to pay higher prices for environmentally-friendly products (Laroche et al., 2001). Some scholars also studied the effect of ecological attitudes and intentions on actual behaviour, finding that there is a positive association between these two sets of constructs (Chan, 2001; Mostafa, 2007). Finally, a few studies focused on consumer attitudes and responses towards environmental advertising (Schuhwerk \& Lefkoff-Hagius, 1995) and dealt with the implications of 'greenwashing' on consumer perceptions and actions (Newell et al., 1998).

\section{Conceptual model and hypotheses}

Our conceptual framework consists of four major parts: antecedent forces, attitudinal factors, behavioural factors, and outcomes (see Figure 1). ${ }^{1}$ Antecedent forces comprise three sets of background consumer parameters, namely cultural ('collectivism' and 'long-term orientation'), political ('political action' and 'liberalism'), and ethical ('deontology' and 'law obedience'). Attitudinal factors refer to the pro-environmental attitudes of the consumer, and these are divided into 'inward', that is, attitudes referring to the abuse of the environment by individual consumers, and 'outward', that is, attitudes about the perceived need for social, political and legal changes to protect the environment (Fransson \& Garling, 1999; Kilbourne \& Pickett, 2008; Sarigöllü, 2009). Behavioural factors include the environmentally-friendly behaviour of the consumer, which can be 'green purchasing', that is, activities that lie in the personal domain and have a direct effect on the natural environment, or 'general environmental', that is, activities that fall under the public domain and have an indirect effect on the natural environment by influencing public policy initiatives (Dietz et al., 1998). Outcomes refer to both satisfaction with the product and satisfaction with life. Sixteen hypothesized associations between the constructs of the model were identified and are presented in the following. 
Figure 1: The conceptual model

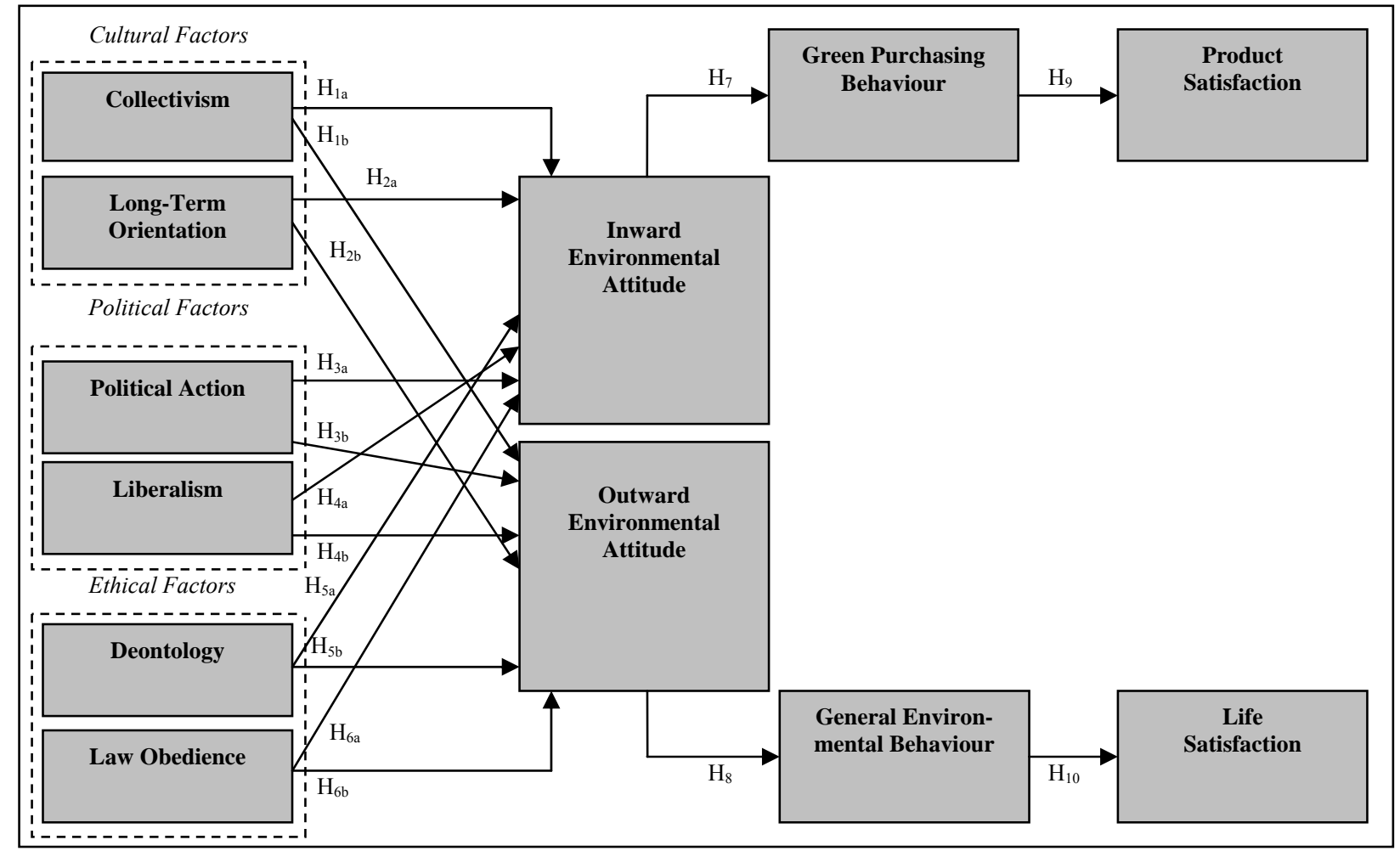

\section{i. Antecedents of environmental attitudes}

Collectivism is the conviction that an individual has regarding his/her interaction with others and denotes interdependence, group-oriented goals, social hierarchies, in-group harmony, and low level of competition (Hofstede, 1980; Triandis, 1995). The behaviour of the people who are collectivistic is usually driven by social norms and by willingness to share scarce resources with others (Sinha \& Verma, 1987). Collectivistic persons are more likely to develop environmentally-friendly attitudes because they tend to demonstrate cooperative behaviour, offer their help promptly to others, and give priority to the goals of the group rather than their personal goals (Kim \& Choi, 2005). In addition, they care about their relationships with others, show concern for the welfare of society, and emphasize the importance of duties and obligations (Hofstede, 1980; Laroche et al., 1999). In many cases, being collectivistic indicates that one may 
forgo personal motivations (e.g., inconvenience caused by recycling) for those that are good for the group (e.g., keeping the environment clean). Thus, a person who thinks collectively is expected to protect the environment so that the whole society, including himself/herself, can enjoy prosperity (McCarty \& Shrum, 1994). The positive association between collectivism and environmentally-friendly attitudes (both inward and outward) was repeatedly confirmed in previous empirical studies (e.g., Ling-yee, 1997; Chan, 2001; McCarty \& Shrum, 2001). Based on the above argumentation, we may predict that:

\section{$H_{1 a}$ : The more collectivistic the consumer is, the more positive his/her inward environmental attitude $H_{1 b}$ : The more collectivistic the consumer is, the more positive his/her outward environmental attitude}

Long-term orientation refers to the prospects perceived by an individual that a society will be in a position to overcome its problems over time (Hofstede, 1980). It is the extent to which an individual has a pragmatic future-oriented perspective (fostering virtues like perseverance and thrift), rather than a conventional historic or short-term point of view (Furrer et al., 2000; Hofstede, 1991). A long-term oriented person preserves social traditions, adheres to family values, and considers reliability, responsiveness, and empathy to be extremely important (Furrer et al, 2000). Since s/he preserves traditions and history, $\mathrm{s} / \mathrm{he}$ is also likely to respect and preserve the environment, in order to reap benefits for his/her family and friends at a later stage and maintain sustainable conditions for future generations to prosper. In fact, recent research has shown that long-term oriented people tend to develop attitudes pertaining to the protection of the natural environment (Joreiman, Van Lange, \& Van Vugt, 2004; Sarigöllü, 2009). Such attitudes may concern eco-friendly actions taking place within the household (e.g., decrease in home consumption) and/or the society at large (e.g., favouring anti-pollution legislation). The following hypotheses can, therefore, be made: 


\section{$H_{2 a}$ : The more long-term-oriented the consumer is, the more positive his/her inward environmental attitude \\ $H_{2 b:}$ The more long-term-oriented the consumer is, the more positive his/her outward environmental attitude.}

An individual's political action denotes a desire to be involved in various socio-political issues, ranging from low-risk, passive, and institutionalized acts to high-risk, active, and unconventional behaviour (Corning \& Myers, 2002). Such political involvement may include, for example, lobbying political representatives, boycotting companies, and participating in pressure groups, political parties, or other organisations (Braithwaite, 1997). According to Corning and Myers (2002), there are several external and internal factors that may influence political action, such as: (a) intergenerational effects, e.g., people with politically active parents are more likely to be active themselves; (b) new social environments, e.g., persons entering a university may encounter activists who may recruit them; (c) goal fulfilment, e.g., failure to achieve personal objectives can lead individuals to the reduction of political action in favour of other activities; and (d) changes in life circumstances, e.g., raising children may reduce the time available for engagement in political activities. Given that the access to and use of environmental resources have to do with issues relating to values, power, and cooperation, environmental protection is inherently political (Hampel, Holdsworth, \& Boldero, 1996). Since the protection of the environment is an issue of major public concern in modern societies, politically active people are very likely to pay attention to and develop attitudes toward its preservation (Bohlen et al., 1993; Owen \& Videras, 2006). Thus, political action may affect the formation of environmentalfriendly attitudes taking place at the individual level (e.g., recycling products at home), as well as the society in general (e.g., keeping the environment clean). We may, therefore, hypothesize that: 


\section{$H_{3 a}$ : The more politically active the consumer is, the more positive his/her inward environmental attitude \\ $H_{3 b}$ : The more politically active the consume is, the more positive his/her outward environmental attitude}

Liberalism refers to the political ideology that falls on the "left" dimensions of the broad left-right cleavage (Roberts, 1996). People with liberalistic views believe that companies should be controlled in terms of their actions and outcomes, especially when these are harmful to society (Hine \& Gifford, 1991; Straughan \& Roberts, 1999). In this respect, a politically liberal person is more likely to have an environmentally-friendly spirit, since organisations usually resist the environmental regulations imposed by governments. This is because environmental reforms affect business operations in three major ways: (a) they incur high costs in technological equipment and operating activities; (b) they introduce additional regulations and increase government intervention in business affairs; and (c) they require innovation in production methods and selling activities (Dunlap, 1975; Van Lierre \& Dunlap, 1979). Empirical evidence shows that politically liberal individuals are more likely to engage in both sustainable consumption habits and actions toward protecting the environment (Dunlap, 1975; Van Liere \& Dunlap, 1981; Hine \& Gifford, 1991; Straughan \& Roberts, 1999; Olli, Grendstad, \& Wollebark, 2001). The following hypothesis can therefore be made:

\section{$\mathrm{H}_{4 \mathrm{a}}$ The more liberal the consumer is, the more positive his/her inward environmental attitude \\ $\mathrm{H}_{4 \mathrm{~b}}$ : The more liberal the consumer is, the more positive his/her outward environmental attitude}

Deontology is an ethical approach that focuses on whether the intention and/or consequences of a certain act is right or wrong (Chan et al., 2008). A deontological individual abides by ethical values, adheres to specific principles, and protects his/her own rights and 
duties which others are required to respect. S/he is also more ready to learn the rules that govern the situations encountered, as well as become more sensitive to any violation of them (Sparks \& Merenski, 2000). This makes a person more mature and responsible toward the environment which $\mathrm{s}$ /he wants to preserve because it is the right thing to do, while at the same time condemning any harmful actions. A person adopting a deontological approach claims an absolute right to life for humans, animals, plants, or ecosystems (Spash, 1997; O’Neill \& Spash, 2000). Such a deontological approach to the environment is based on the premise that there are distinct moral rules or duties, violation of which is intrinsically wrong and observance is intrinsically right (Brennan, 2002). In this respect, the environment has a moral right to be properly treated, while, at the same time, people have a moral duty to protect it. Respecting rights and fulfilling duties pertaining to the environment forms an eco-friendly consumer attitude (García-Rosell \& Moisander, 2008). Thus, on the basis of the above, we may posit that:

\section{$\mathbf{H}_{5 \mathrm{a}}$ : The more deontological the consumer is, the more positive his/her inward environmental attitude \\ $\mathrm{H}_{5 \mathrm{~b}:}$ The more deontological the consumer is, the more positive his/her outward environmental attitude}

The final antecedent factor is law obedience, which is defined as the extent to which an individual respects the laws of his/her country (Gaski, 1999). Human actions are expected to conform to national laws, otherwise punishments can be imposed by courts or other authorities. Environmentally-related legislation has grown enormously in recent decades, regulating the behaviour and actions not only of organisations (e.g., laws controlling the amount of $\mathrm{CO}_{2}$ emissions), but also those of consumers (e.g., laws prohibiting the littering of the environment). A law obedient person is expected to respect environmental laws, is willing to make personal sacrifices to preserve the environment, and positively influences his/her relatives and friends to 
become environmentally-friendly (Gaski, 1999). S/he is also likely to avoid mixing with other people who do not show respect to environmental laws, as well as, condemn organisations that do not conform to environmental standards set by legislation in terms of their production process, business policies, and end products. Hence, the following hypothesis can be formulated:

\section{$\mathrm{H}_{6 \mathrm{a}}$ The more law obedient the consumer is, the more positive his/her inward environmental attitude $\mathrm{H}_{6 \mathrm{~b}:}$ The more law obedient the consumer is, the more positive his/her outward environmental attitude}

\section{ii. Environmental attitudes and behaviour ${ }^{2}$}

Consumers who adopt an eco-friendly attitude believe that the ecological situation on the planet is deteriorating and, therefore, it is necessary to take drastic measures toward protecting the environment (Banerjee \& McKeage, 1994; Schlegelmilch et al., 1996). Although such a proenvironmental attitude incurs inconveniences (e.g., extra effort to recycle goods), additional costs (e.g., more expensive green products), and lower levels of product performance (e.g., cars with lower horsepower), consumers having this attitude are more likely to engage in an ecologically friendly purchasing behaviour, such as avoiding non-disposable merchandise, looking for recyclable products, and buying biodegradable goods (Shabecoff, 1993; Kalafatis et al., 1999; Laroche et al., 2001). This is in harmony with the cognitive consistency theory (Festinger, 1957), which argues that an individual who is concerned about ecological problems is very likely to be motivated to take actions that will minimize them. In fact, many studies (e.g., Schlegelmilch et al., 1996; Roberts \& Bacon, 1997; Mostafa, 2007; Kilbourne \& Pickett, 2008) have empirically shown that consumers who are environmentally sensitive are very likely to change their behaviour and purchase products that are friendly to the environment, as well as influence other people toward adopting an ecological approach to their consumption. Based on the above, we may posit that: 


\section{$\mathrm{H}_{7}$ : The more positive the inward environmental attitude of the consumer is, the more intense his/her green purchasing behaviour.}

As opposed to inward environmental attitude which affects more 'private' actions, an outward environmental attitude refers to a more 'public' involvement of an individual with the society and its problems, particularly those related to the protection of the environment (Stern, 2000). A person with such attitude shows great interest in social, political, legal and other issues pertaining to the protection of the natural environment, and for each of these issues $\mathrm{s} / \mathrm{he}$ has his/her own views and suggestions of how it should be approached (Fransson \& Garling, 1999; Kilbourne \& Pickett, 2008). Individuals having an outward environmental attitude can demonstrate various types of behaviour, which can have a direct effect on public policy-making (e.g., putting pressure on political parties, increasing bargaining power of environmental lobbies, becoming a member of an environmental group), but an indirect effect on the natural environment (e.g., new policy on environmental preservation, new rules for animal hunting, harmonization with international environmental standards) (Dietz et al., 1998; Stern, 2000). A number of empirical studies found that consumer attitudes about the state of the natural environment are positively associated with such behaviour (Stern et al., 1999; Steg et al., 2005; Kilbourne \& Pickett, 2008). Hence, the following hypothesis can be made:

\section{$\mathrm{H}_{8}$ : The more positive the outward environmental attitude of the consumer is, the more intense his/her environmental behaviour}

\section{iii. Consumer behaviour and satisfaction}

Green purchasing behaviour refers to the preference and use of products that are friendly to the environment and/or have been produced using ecological processes and materials (Kilbourne \& Pickett, 2008). A number of benefits are derived from the adoption of eco-friendly purchasing 
behaviour, such as health, safety, symbolism, and status (Ottman et al., 2006). Consumers performing environmentally-friendly actions tend to think highly of themselves as the kind of persons who care for the environment (Thogersen \& Compton, 2009). In fact, a recent study has shown that many consumers increasingly opt for a less wasteful life (e.g., switching off lights, recycling more, buying less) and show a strong interest in green consumption because they derive personal satisfaction from it (Flatters \& Willmott, 2009). This satisfaction is not attributed only to the good performance of green products, but also to a feeling that the individual does not harm the environment (Bodet, 2008; Chen, 2010). Based on the above, we may posit that:

\section{$\mathrm{H}_{9:}$ The greener the purchasing behaviour of the consumer is, the greater his/her satisfaction with the product}

Environmental behaviour includes all those elements in the psychology of an individual that reflect his/her sensitivity to environmental issues, such as saving energy, keeping places clean, and avoiding waste (Kilbourne \& Pickett, 2008). Such behaviour is expected to make the consumer generally satisfied with his/her life, because of a belief that s/he has contributed, at both an individual and group level, to protecting the environment (Light et al., 1985). Mayer and Frantz (2004) argue that people derive a sense of well-being from feeling connected to nature, and those who are more connected to it experience a higher level of life satisfaction. The latter is considered to be the ultimate goal in life and is defined as the degree to which a person judges the overall quality of his/her life favourably (Paim, 1995; Sirgy, 1998; Selim, 2008). Individuals are satisfied with their lives when they rationally harmonize their outer and inner world so as to live in a self-sufficient way, and the adoption of environmentally-friendly behaviour helps toward achieving this harmonization (Dierksmeier \& Pirson, 2009). In fact, several empirical studies (Eigner, 2001; Sohr, 2001; Nisbet, Zelenski, \& Murphy, 2010) have 
shown that life satisfaction can be enhanced by caring about nature and protecting one's valued environment. Hence, we may posit the following:

\section{$H_{10:}$ The more intense the general environmental behaviour of the consumer is, the greater the satisfaction with his/her life}

\section{Investigation method}

The study took place in Cyprus, which provides fertile ground for environmental marketing research for five major reasons: (a) it has recently joined the European Union, thus requiring the application of strict rules and regulations to protect the environment; (b) it is currently implementing a series of environmental protection programs at the national level (e.g., recycling packaging); (c) it is characterized by well-educated and demanding consumers, who are increasingly concerned about environmental matters; (d) it has a strong ecological movement, as well as various other pressure groups caring about the protection of the environment; and (e) it is relatively small in size, both in geographic and demographic terms, thus allowing for more efficient face-to-face research among consumers.

A nationwide sample of 500 consumers aged 15 and above was selected, using stratified random sampling procedures. The sample was representative of the country's population in terms of gender (male: $49.2 \%$, female: $50.8 \%$ ), age (15-24 years: $18.9 \%, 25-34$ years: $19.3 \%, 35$ 44 years: $17.4 \%, 45-54$ years: $16.6 \%, 55-64$ years: $12.9 \%, 65$ years or more: $14.9 \%$ ), population density (urban: 69.7\%, rural: 30.3\%), and geographic region (Nicosia: 39.5\%, Limassol: 28.7\%, Larnaca: $16.7 \%$, Pafos: 9.6\%, Famagusta: 5.5\%).

Data were gathered through personal interviews conducted at central locations of the country over a six-week period. Interviews were based on a structured questionnaire which consisted of five major parts, namely antecedent factors, environmental attitudes, consumer behaviour, consumer satisfaction, and demographic characteristics. The questions in 
the questionnaire contained lists of pre-coded items relating to scales derived from the pertinent literature, which were measured on a 7-point Likert type scale. The questionnaire was written in English, translated into Greek, and then back-translated into English to achieve linguistic consistency. Prior to launching the full-scale study, the questionnaire was pilot-tested with ten individuals to ensure its workability. Due to the rigorous interview procedure undertaken, all questionnaires were fully completed and contained no missing values. Each questionnaire was carefully edited before data were entered for computer analysis.

Due to the multi-facet nature of the conceptual model, the scales of the constructs employed were derived from multiple sources. The scale of 'collectivism' consisted of five items and was derived from McCarty and Shrum (2001), while 'long-term orientation' was a four-item scale developed by Hofstede (1980). 'Political action' comprised four items adapted from Bohlen et al. (1993) and the four-item scale of Roberts (1996) was used to operationalize 'liberalism'. 'Deontology' and 'law obedience' had four items each, and these were extracted from Chan et al. (2008) and Gaski (1999) respectively. The scale for 'environmental attitudes' was derived from Kilbourne and Pickett (2008), but this was split into 'inward' and 'outward', each incorporating four items. The same source also provided the scale for 'purchasing behaviour' (five items) and 'environmental behaviour' (four items). Finally, the product satisfaction scale was taken from Bodet (2008) and included five items, while a four-item scale for life satisfaction was adapted from Light et al. (1985).

To test the proposed conceptual model and the hypothesized associations among the constructs, structural equation modelling (SEM) was employed for three major reasons: (a) it allows assessment of relationships between the constructs of the model in a comprehensive, systematic and holistic way; (b) it takes a confirmatory rather than an exploratory approach to the 
data analysis; and (c) it takes into account explicit estimates of measurement error, whereby the fit of the conceptual model is considered (Byrne, 2006; Hair et al., 2006). The analysis was performed using the EQS statistical program, which, compared to other available programs, places less stringent assumptions on the multivariate normality of the data (Bentler, 2006).

\section{Research findings}

The descriptive statistics (mean scores and standard deviations) of the constructs and items used for the purposes of this study are presented in Table 1. To assess the validity and reliability of these constructs and their scales used, two measurement models were estimated. The first included all the antecedent forces (i.e., cultural, political, and ethical), and the second contained attitudinal factors (i.e., inward and outward environmental attitude), behavioural factors (i.e., green purchasing behaviour, environmental behaviour) and outcome constructs (i.e., product satisfaction, life satisfaction).

\section{... Insert Table 1 about here ...}

The chi-square statistic for both models was found to be significant $\left(\chi_{(524)}^{2}=935.92\right.$, $p<.01$ for Model $A$ and $\chi_{(284)}^{2}=944.52, p=.000$ for Model B) (see Table 2). However, given the known weaknesses of this fit statistic (Bagozzi \& Yi, 1988; Kline, 2006), the alternative fit indices were employed to assess the goodness-of-fit for both models, revealing values within the commonly accepted critical levels (Hair et al., 2006). Specifically, the Root Mean Square Error of Approximation (RMSEA) was 0.06 for Model A and 0.07 for Model B respectively $(\leq 0.08)$, the Normed Fit Index (NFI) was 0.96 for Model A and 0.97 for Model B respectively ( $\geq 0.95)$, the Non-Normed Fit Index (NNFI) was 0.97 for Model A and 0.98 for Model B respectively ( $\geq$ 0.95), and the Comparative Fit Index (CFI) was 0.98 for both models $(\geq 0.95)$. Overall, the 
results of both models provided a good fit to the data observed (Byrne, 2006; Hair et al., 2006).

\section{... Insert Table 2 about here ...}

Convergent validity was satisfactory, since all items loaded highly on their designated constructs. Specifically, the factor loadings for all items comprising each construct were above 0.60 , while the $t$-value for each item was significant and greater than 12.0, and all standard errors of the estimated coefficients were very low. Discriminant validity was also evident, as indicated by the results of the two alternative methods recommended by Anderson and Gerbing (1988): in the first approach it was observed that the confidence interval around the correlation estimate $(+/-$ two standard errors $)$ for each pair of constructs examined never included 1.0; in the second approach, it was found that for each pair of constructs examined the chi-square difference between the unconstrained and constrained model was always statistically significant $\left(\Delta \chi_{(1)}^{2}>\right.$ $3.84 ; \mathrm{p}<.05)$, while the fit was significantly worse. Construct reliability was also high and well above the recommended cut-off point of .70 (Nunnally \& Bernstein, 1994), as the individual Cronbach's alpha $(\alpha)$ scores for every construct ranged from .78 to .92 and composite reliability ( $\rho$ ) coefficients ranged from .72 to .87 . It can, therefore, be concluded that the measurement procedure employed was highly accurate, precise, and valid, while, at the same time, reliably identifying the theoretical constructs as elements of the structural model (Bagozzi \& Yi, 1988). The inter-correlations among the constructs employed are presented in Table 3.

\section{... Insert Table 3 about here ...}

The hypothesized links between the constructs were tested by estimating the structural model using the elliptical re-weighted least squares (ERLS) technique. Although the Chi-square

for the model was found to be significant $\left(\chi^{2}=4965.76, p=.000\right)$, this was expected due to the known limitations of this statistic (Kline, 2006). Subsequently, we used the alternative fit indices 
which revealed an acceptable structural model fit $(\mathrm{NFI}=.95 ; \mathrm{NNFI}=.96 ; \mathrm{CFI}=.96$; $\mathrm{RMSEA}=$ $.08)$. The standardized path coefficients, together with the corresponding $t$-values of the structural model, are presented in Table 4. With the exception of $\mathrm{H}_{4 a}$ and $\mathrm{H}_{4 b}$, all theoretical links examined were found to be statistically significant.

\section{... Insert Table 4 about here ...}

With regard to cultural factors, collectivism was found to be conducive to the formation of both inward $\left(\mathrm{H}_{1 \mathrm{a}}: \beta=.21, t=6.70, p=.00\right)$ and outward environmental attitudes $\left(\mathrm{H}_{1 \mathrm{~b}}: \beta=.17, t=4.01\right.$, $p=.00$ ). These results support our initial hypotheses and are in agreement with prior research (e.g., Ling-yee, 1997; McCarty \& Shrum, 1994; 2001) showing that a person who is driven by collectivistic values is very likely to favour ecologically-friendly consumption and care about the preservation of ecological well-being. Nonetheless, these results also contrast the findings of other researchers (e.g., Laroche et al., 2001; Kim \& Choi, 2005), who found no association between collectivism and environmental concerns of consumers. Although long-term orientation was found to be positively related to outward environmental attitude $\left(\mathrm{H}_{2 \mathrm{~b}}\right.$ : $\left.\beta=.11, t=2.58, p=.01\right)$, the link with inward environmental attitude, although significant, was found to be in the opposite sign to that hypothesized $\left(\mathrm{H}_{2 \mathrm{a}}: \beta=-.17, t=-5.33, p=.00\right)$. This is a surprising finding which partially supports the results of past research (e.g., Joreiman et al., 2004; Sarigöllü, 2009). investigating the link between these two constructs

With reference to political factors, political action was found to be positively linked with both inward $\left(\mathrm{H}_{3 \mathrm{a}}: \beta=.18, t=5.83, p=.00\right)$ and outward $\left(\mathrm{H}_{3 \mathrm{~b}}: \beta=.009, t=2.08, p=.04\right)$ environmental attitudes. This confirms the findings of previous studies that an individual's political involvement exposes him/her to ecological issues and helps to cultivate an interest in preserving the environment (Bohlen et al., 1993; Owen \& Videras, 2006). However, no relationship was 
observed between liberalism and inward $\left(\mathrm{H}_{4 \mathrm{a}}: \beta=-.03, t=-1.01, p=.31\right)$ or outward $\left(\mathrm{H}_{4 \mathrm{~b}}: \beta=-.03\right.$, $t=-0.65, p=.52)$ environmental attitudes. This is another unexpected finding that contradicts the results of past empirical research in the field (e.g., Straughan \& Roberts, 1999; Olli et al., 2001). Perhaps, this could be explained by the growing public concern about the protection of the environment (Laroche et al., 2001), which has transcended political affiliations and ideologies (Roberts, 1996). Hence, pro-environmental attitudes are by no means restricted to people belonging to the liberal segments of the society.

Ethical factors proved to be strong drivers behind the development of eco-friendly attitudes. Specifically, positive relationships were established between deontology and an environmental attitude of an inward $\left(\mathrm{H}_{5 \mathrm{a}}: \beta=.88, t=16.22, p=.00\right)$ or outward $\left(\mathrm{H}_{5 \mathrm{~b}}: \beta=.46, t=9.47, p=.00\right)$ nature. This confirms the findings of previous studies on the subject (e.g., Spash, 1997, O'Neill \& Spash, 2000; Chan et al., 2008), whereby people with strong deontological views believe that they have a moral duty towards humanity to protect the environment. Law obedience was also positively associated with inward $\left(\mathrm{H}_{6 \mathrm{a}}: \beta=.18, t=5.90, p=.00\right)$ and outward $\left(\mathrm{H}_{6 \mathrm{~b}}: \beta=.53, t=10.05, p=.00\right)$ environmental attitudes. This is actually the first empirical validation of this association which gives credibility to the notion that, in light of the increasing environmental legislation in many countries, a law obedient person is willing to make personal sacrifices to protect the environment and take actions against those violating such legislation (Gaski, 1999).

In accord with our hypotheses, an inward environmental attitude was found to be a significant predictor of green purchasing behaviour $\left(\mathrm{H}_{7}: \beta=.90, t=15.83, p=.00\right)$, while an outward environmental attitude positively affected environmentally-friendly behaviour $\left(\mathrm{H}_{8}: \beta=.39, t=6.44\right.$, $p=.00$ ). This is in accord with growing empirical evidence that stress the instrumental role of environmental attitudes in shaping environmentally-friendly behavioural intentions and actions 
(Kalafatis et al. 1999; Mostafa, 2007; Nigbur, Lyons and Uzzell, 2010). It is also in harmony with the results of Kilbourne and Pickett's (2008) study, where it was shown that as opposed to inward environmental attitudes which stress 'private' sphere pro-environmental behaviour (e.g., consuming green products, recycling packaging, purchasing organic goods), outward environmental attitudes promote 'public' pro-environmental behaviour (e.g., joining environmental groups, contributing to environmental funds, signing petitions).

Finally, the study confirmed that eco-friendly purchasing behaviour is conducive to product satisfaction $\left(\mathrm{H}_{9}: \beta=.86, t=16.17, p=.00\right)$, while individuals demonstrating general environmental behaviour increase their life satisfaction $\left(\mathrm{H}_{10}: \beta=.73, t=10.21, p=.00\right)$. This supports the prevailing notion among scholars in the field that direct (e.g., through eco-product purchases) or indirect (e.g., through a pro-ecological public stance) support of the environment, increases product satisfaction (Flatters \& Willmott, 2009) and enhances quality of life (Thøgersen \& Compton, 2009) respectively. This is also in accord with prior empirical research in sociology and psychology about the crucial effects of eco-friendly attitudes on personal happiness, satisfaction, and well-being (Sohr, 2001; Mayer, \& Frantz, 2004; Nisbet et al., 2010). Finally, both findings point to a mutually beneficial relation between sustainability, consumption and life, where personal and planetary well-being can co-exist in a harmonious manner.

\section{Summary and conclusions}

Our study contributes to the marketing literature in multiple ways: first, it is one of the very few studies that it puts together in a single model various motives, attitudes, behaviour, and satisfaction of consumers with regard to ecological issues; second, it concurrently examines the role of various factors pertaining to cultural, societal, and ethical issues in forming environmental 
attitudes by consumers; third, it draws a clear distinction between environmental attitudes and behaviour, as opposed to the bulk of previous research which treated them interchangeably; fourth, it distinguishes between inward and outward environmental attitudes, each having their own impact on specific aspects of consumer behaviour; and finally, it combines for the first time both micro and macro eco-marketing issues, often examined separately by previous research.

The results of the preceding analysis have clearly shown that certain cultural, political, and ethical factors are responsible for the adoption of an environmental attitude by consumers, whether when specifically making personal purchasing decisions (inward) or when broadly considering issues relating to society (outward). In brief, a pro-environmental attitude is more likely to occur when the consumer is collectivistic, long-term oriented, politically active, deontological, and law obedient. The direction of this attitude, whether inward or outward, will subsequently have its effect on different aspects of consumer behaviour and its outcomes: while an inward environmental attitude will stimulate green purchasing behaviour and higher product satisfaction, an outward environmental attitude will cause general pro-environmental actions which will subsequently lead to greater life satisfaction.

This study also revealed that an individual can simultaneously exhibit both inward and outward environmental attitudes, with each of them influencing a different aspect of behaviour. While inward environmental attitude is more associated with green purchasing behaviour, outward environmental attitude mainly refers to general green behaviour. This finding can help to resolve a curious paradox often cited in the literature, whereby ecologically concerned consumers were not consistently found to prefer environmentally-friendly products in their purchases (Kilbourne \& Pickett, 2008). In other words, a person with an outward environmental attitude can act in a friendly way to the general environment, but is not necessarily involved in a 
green purchasing behaviour, which is the result of the development of an inward green attitude.

The fact that different types of satisfaction are affected by different levels of environmental friendly behaviour is also an important finding, since it combines both macro and micro perspectives of green consumer behaviour. While at the macro level, an individual who exhibits a general ecological behaviour will enjoy more satisfaction with his/her life, at the micro level, consumers whose purchasing behaviour is eco-friendly will feel more satisfied with their green buying options. These two levels of satisfaction can co-exist and complement each other in such a way that the individual's overall well-being is enhanced.

\section{Implications}

These findings have various implications for both corporate and public policymakers. Managers should appreciate the fact that consumers derive high levels of product and life satisfaction from ecological behaviour. Hence, they should become more ecologically-oriented in their production methods, marketing approaches, and products offered to the market (Peattie, 1999). They should also investigate in more detail the cultural, political, and ethical characteristics of their target markets and try to adjust their company offerings according to whether or not their consumers are characterized by an environmentally-friendly attitude. Different segments of green consumers could also be identified, according to their eco-friendly attitudes, and attractive company offerings should be designed for each segment (Diamantopoulos et al., 2003). For example, communication efforts can emphasize collectivistic arguments (e.g., importance of eco-behaviour for society as a whole), tradition-oriented messages (e.g., need for next generations to have a place in which to live and prosper), political-related points (e.g., vote for the environment), deontological-related claims (e.g., it is your moral duty to respect the environment), and legally- 
related statements (e.g., it is against the law to litter the streets). Ecologically sensitive organisations should also systematically assess the pro-environmental behaviour of their current and potential customers in order to adjust their marketing programs accordingly. It is also important to measure customer satisfaction (both at the product and life level) at regular intervals, so as to retain and expand the firm's customer base.

On the other hand, public policymakers should try, through proper educational, regulatory, communication, and other policies, to cultivate a spirit among their citizens that is characterized by collectivism, long-term orientation, political action, deontology, and law obedience. In addition, although many governments and local authorities are becoming increasingly more sensitive to environmental issues, it is important to allocate more resources to provide the necessary means (e.g., offering recycling facilities) to individuals to easily engage in pro-environmental behaviour. This is because the time, effort, and inconvenience associated with pursuing eco-friendly behaviour were often named reasons for postponing its adoption and limiting its development (Follows \& Jobber, 2000; Cornelissen, Pandelaere, Warlop, \& Dewitte, 2008). The fact that an outward pro-environmental attitude is conducive toward ecological behaviour, which subsequently leads to a feeling of well-being, implies that public policymakers should take measures centring on the benefits of environmentalism for the individual (e.g., higher quality of life) and the society at large (e.g., increased standards of living). This can be achieved, for example, through special education programs (e.g., environmental sustainability courses), information dissemination (e.g., door-to-door brochures for recycling waste), and even monetary incentives (e.g., prizes awarded to citizens demonstrating exceptional ecological behaviour).

\section{Future directions}

The importance of our findings at both business and government levels necessitates the 
replication of the study in other countries, with different economic, socio-cultural, and politicallegal settings. For instance, it would be interesting to investigate environmental consumer behaviour in China, where lack of environmental concern is more evident (Chan \& Lau, 2000). It would also be insightful to draw comparisons on consumer eco-friendly attitudes and behaviour between developed and developing countries, as well as between mature and emerging markets,

It is also important to examine the effect of consumer demographics, such as age, gender, education, family cycle, and income group, on the link between antecedent factors and proenvironmental attitudes. The use of socio-demographic parameters as moderators, rather than determinants, of consumer ecological attitude could perhaps yield more solid insights. The incorporation of psychographic factors, such as those pertaining to the lifestyle characteristics of the individual, could also have a strong moderating effect.

Although the list of antecedent factors used in this study is quite extensive and diverse, it would be useful if additional cultural (e.g., uncertainty avoidance), political (e.g., autocracy), and ethical (e.g., idealism) parameters were examined. Moreover, other unexplored factors pertaining to consumer behaviour, such as personality traits, emotional intelligence, and preference for consistency, should be considered as potential drivers of an environmentally-friendly attitude.

Finally, it is crucial to monitor consumer environmental attitude and behaviour over time, as a result of variations in antecedent factors caused by changes in their 'private' and/or 'public' environment. In this respect, it is important to embark on a longitudinal study among a panel of consumers, whose motivations, attitudes, behaviour, and outcomes relating to ecological issues will be monitored at regular intervals. This will help to determine potential internal and external triggering cues of consumer eco-friendly approaches, as well as identify any distinct evolutionary phases in the adoption of pro-environmental attitude and behaviour. 


\section{Notes}

1. An 'antecedent' refers to a factor that precedes a specific attitude or behavior, while an 'outcome' is the result of this attitude or behaviour. Although these terms may have a temporal connotation (in the sense that first 'antecedents' take place, then attitude or behaviour is formulated, and 'outcome' is the finality) many cross-sectional studies (e.g., Dröge \& Halstead, 1991; Menon, Bharadwaj, Adidam, \& Edison, 1999; Myers, Daugherty, \& Autry, 2000; Atuahene-Gima \& Murray, 2004; Alden, Steenkamp, \& Batra, 2006; Cleveland, Laroche, \& Papadopoulos, 2009; and Walsh, Mitchell, Jackson, \& Beatty, 2009) have extensively used this terminology to express the causal relationships among constructs.

2. Consumer attitudes and behaviour are two entirely different concepts: while an attitude is a lasting, general evaluation of people (including oneself), objects or issues, behaviour is a consumer's actions with regard to an attitude object (Solomon, Bamossy, Askegaard, \& Hogg, 2010). However, consumer attitudes do not always result in actual behaviour, because certain internal (e.g., financial limitations) or external (e.g., socio-political changes) factors may inhibit the materialization of the expected behaviour. 


\section{References}

Aitken, L. (2006). Green works. Campaign (UK), 28, 26-27.

Alden, D.L., Steenkamp, J.-B.E.M., \& Batra, R. (2006). Consumer attitudes toward marketplace globallization: structure, antecedents and consequences. International Journal of Research in Marketing, 23, 227-239.

Anderson, J.C., \& Gerbing D.W. (1988). Structural equation modeling in practice: A review and recommended two-step approach. Psychological Bulletin, 103, 411-423.

Anderson, T.W., Henion K.E., \& Cox E.P. (1974). Socially vs. ecologically concerned consumers. AMA Combined Conference Proceedings. Chicago, IL: American Marketing Association, 304-311.

Antil, J.H. (1984). Socially responsible consumers: Profile and implications for public policy. Journal of Macromarketing, 4, 18-32.

Arcury, T.A., Scollay, S.J., \& Johnson, T.P. (1987). Sex differences in environmental concern and knowledge: The case of acid rain. Sex Roles, 16, 463-472.

Atuahene-Gima, K. \& Murray, J.Y. (2004), Antecedents and outcomes of marketing strategy comprehensiveness. Journal of Marketing, 68, 33-46.

Bagozzi, R.P., \& Yi, Y. (1988). On the evaluation of structural equation models. Journal of the Academy of Marketing Science, 16, 74-94.

Balderjahn I. (1988). Personality variables and environmental attitudes as predictors of ecologically responsible consumption patterns. Journal of Business Research, 17, 51-56.

Banerjee, B., \& McKeage, K. (1994). How green is my value: Exploring the relationship between environmentalism and materialism. In Allen, C.T., \& John, D.R. (Eds), Advances in Consumer Research (47-52), Association for Consumer Research.

Banerjee, S.B. (2002). Corporate environmentalism: The construct and its measurement. Journal of Business Research, 55, 177-191.

Barksdale, H.C., \& Darden, W.R. (1972). Consumer attitudes towards marketing and consumerism. Journal of Marketing, 36, 28-35.

Bentler, P.M. (2006), Structural equations program manual. Encino, CA: Multivariate Software Inc.

Bodet, G. (2008). Customer satisfaction and loyalty in service: Two concepts, four constructs, several relationships. Journal of Retailing and Consumer Services, 15, 156-162.

Bohlen, G.M., Schlegelmilch, B.B., \& Diamantopoulos, A. (1993). Measuring ecological concern: A multi-construct perspective. Journal of Marketing Management, 10, 415-430.

Braithwaite, V. (1997). Harmony and security value orientations in political evaluation. Personality and Social Psychology Bulletin, 23, 401-414.

Brennan, A. (2002). Environmental ethics. In E.N. Zalta (Ed), The Stanford Encyclopedia of Philosophy.

Brooker, G. (1976). The self-actualizing socially conscious consumer. Journal of Consumer Research, 3, 107-112.

Byrne, B.M. (2006), Structural equation modelling with EQS: Basic concepts, applications, and programming (2nd ed.). London: Lawrence Erlbaum Associates.

Chan, K. (1999). Market segmentation of green consumers in Hong Kong. Journal of International Consumer Marketing, 12, 7-24.

Chan, R., Wong, Y., \& Leung, T. (2008). Applying ethical concepts to the study of green consumers' intentions to bring their own shopping bags. Journal of Business Ethics, 79, 469481.

Chan, R.Y.K (2001). Determinants of Chinese consumers' green purchase behaviour. 
Psychology \& Marketing, 18, 339-413.

Chan, R.Y.K., \& Lau, L.B.V. (2004). The effectiveness of environmental claims among Chinese consumers: Influences of claim type, country disposition and ecocentric orientation. Journal of Marketing Management, 20, 273-319.

Chen, Y.-S. (2010). The drivers of green brand equity: Green brand image, green satisfaction, and green trust. Journal of Business Ethics, 93, 307-319.

Cleveland, M., Laroche, M. and Papadopoulos, N. (2009). Cosmopolitanism, consumer ethnocentrism, and materialism: An eight-country study of antecedents and outcomes. Journal of International Marketing, 17, 116-146.

Cornelissen, G., Pandelaere, M., Warlop, L., \& Dewitte, S. (2008). Positive cueing: Promoting sustainable consumer behaviour by cueing common environmental behaviours as environmental. International Journal of Research in Marketing, 25, 46-55.

Corning, A.F., \& Myers, D.J. (2002). Individual orientation toward engagement in social action. Political Psychology, 23, 703-729.

Diamantopoulos, A., Schlegelmilch, B.B., Sinkovics, R.R., \& Bohlen, G.M. (2003). Can sociodemographics still play a role in profiling green consumers? A review of the evidence and an empirical investigation. Journal of Business Research, 56, 465-80.

Dierksmeier, C., \& Pirson, M. (2009). Oikonomia versus chrematistike: Learning from Aristotle about the future orientation of business management. Journal of Business Ethics, 88, 417-430.

Dietz, T., Stern, P.C., \& Guagnano, G.A. (1998). Social structural and social psychological bases of environmental concern. Environment and Behavior, 30, 450-471.

Dröge, C., \& Halstead, D. (1991). Postpurchase hierarchies of effects: The antecedents and consequences of satisfaction for complainers versus non-complainers. International Journal of Research in Marketing, 8, 315-328.

Dunlap, R.E. (1975). The impact of political orientation on environmental attitudes and actions. Environment and Behavior, 7, 428-454.

Dunlap, R.E., \& Van Liere, K.D. (1978). Proposed measuring instrument and preliminary results: The "new environmental paradigm". Journal of Environmental Education, 9, 10-19.

Eigner, S. (2001). The relationship between protecting the environment as a dominant life goal and subjective well-being. In P. Schmuck and K.M. Sheldon (eds.), Life goals and well-being: Towards a positive psychology of human striving (182-201). Seattle, WA: Hogrefe and Huber.

Ellen, P.S., Wiener, J.L., \& Cobb-Walgren, C. (1991). The role of perceived consumer effectiveness in motivating environmentally conscious behaviours. Journal of Public Policy \& Marketing, 10, 102-117.

Festinger, L. (1957). A theory of cognitive dissonance. Evanston, IL: Row Peterson.

Fisk, G. (1973). Criteria for a theory of responsible consumption. Journal of Marketing, 37, 2431.

Flatters, P., \& Willmott, M. (2009). Understanding the post-recession consumer. Harvard Business Review, July-August, 106-112.

Follows, S.B., \& Jobber, D. (2000). Environmentally responsible purchase behaviour: A test of a consumer model. European Journal of Marketing, 34, 723-746.

Fransson, N., \& Garling T. (1999). Environmental concern: conceptual definitions, measurement methods, and research findings. Journal of Environmental Psychology, 19, pp. 369-382.

Furrer, O., Liu, B.S.-C., \& Sudharshan, D. (2000). The relationships between culture and service quality perceptions: Basis for cross-cultural market segmentation and resource allocation. Journal of Service Research, 2, 355-371.

García-Rosell, J.-C., \& Moisander, J. (2008). Ethical dimensions of sustainable marketing: A 
consumer policy perspective. European Advances in Consumer Research, 8, 210-215.

Gaski, J.F. (1999). Does marketing ethics really have anything to say? - A critical inventory of the literature. Journal of Business Ethics, 18, 315-334.

Hair, J.F. Jr., Black, W.C., Babin, B.J., Anderson, R.E., \& Tatham, R.L. (2006), Multivariate data analysis (6th ed.). Englwood Cliffs, NJ:Pearson, Prentice-Hall.

Hampel, B., Holdsworth, R., \& Boldero, J. (1996). The impact of parental work experience and education on environmental knowledge, concern and behaviour among adolescents. Environmental Education Research, 2, 287-300.

Heslop, L.A., Moran, L., \& Cousineau, A. (1981). Consciousness in energy conservation behaviour: An exploratory study. Journal of Consumer Research, 8, 299-305.

Hine, D.W., \& Gifford, R. (1991). Fear appeals, individual differences, and environmental concern. Journal of Environmental Education, 23, 36-41.

Hofstede, G. (1980), Culture's consequences: International differences in work-related values, Beverly Hills, CA: Sage Publications.

Hofstede, G. (1991). Cultures and organizations: Software of the mind. London: McGraw-Hill.

Jansson, J., Marell, A., \& Nordlund, A. (2010). Green consumer behavior: Determinants of curtailment and eco-innovation adoption. Journal of Consumer Marketing, 27, 358-370.

Jones, A. (1987). The violence of materialism in advanced industrial society: An eco-sociological approach, The Sociological Review, 35, 19-47.

Joreiman, J.A., Van Lange, P.A.M., \& Van Vugt, M. (2004). Who cares about the environmental impact of cars: those with and eye toward the future. Environment and Behavior, 36, 187-206.

Kalafatis, S.P., Pollard, M., East, R., \& Tsogas, M.H. (1999). Green marketing and Ajzen's theory of planned behaviour: A cross-market examination. Journal of Consumer Marketing, $16,441-460$.

Kilbourne, W., \& Pickett, G. (2008). How materialism affects environmental beliefs, concerns, and environmentally responsible behaviour. Journal of Business Research, 61, 885-893.

Kilbourne, W., McDonagh, P., \& Prothero, A. (1997). Sustainable consumption and the quality of life: A macromarketing challenge to the dominant social paradigm. Journal of Macromarketing, 17, 4-24.

Kilbourne, W.E., \& Beckmann, S.C. (1998). Review and critical assessment of research on marketing and the environment. Journal of Marketing Management, 14, 513-532.

Kilbourne, W.E., Beckmann, S.C., \& Thelen, E. (2002). The role of the dominant social paradigm in environmental attitudes: A multi-national examination. Journal of Business Research, 55, 193-204.

Kim, Y., \& Choi, S.M. (2005). Antecedents of green purchase behaviour: An examination of collectivism, environmental concern, and PCE. Advances in Consumer Research, 32, 592-599.

Kinnear, T.C., Taylor, J.R., \& Ahmed, S.A. (1974). Ecologically concerned consumers: Who are they?. Journal of Marketing, 38, 20-24.

Kline, R.B. (2005), Principles and practice of structural equation modeling ( $2^{\text {nd }}$ ed.). London: The Guilford Press.

Laroche, M., Bergeron, B., \& Barbaro-Forleo, G. (2001). Targeting consumers who are willing to pay more for environmentally friendly products. Journal of Consumer Marketing, 18, 503520.

Levin, G. (1990). Consumers turning green: JWT survey. Advertising Age, 61, 74.

Light, H., Hertsgaard, D., \& Martin, R. (1985). Education and income: Significant factors in life satisfaction of farm men and women. Research in Rural Education, 3, 7-12.

Ling-yee, Li (1997). Effect of collectivism orientation and ecological attitude on actual 
environmental commitment: The moderating role of consumer demographics and product involvement. Journal of International Consumer Marketing, 9, 31-53.

Mayer, F.S., \& Frantz, C.M. (2004). The connectedness to nature scale: A measure of individuals' feelings in community with nature. Journal of Environmental Psychology, 24, 503-515.

McCarty, J., \& Shrum, L. (1994). The recycling of solid wastes: Personal values, value orientations, and attitudes about recycling as antecedents of recycling behaviour. Journal of Business Research, 30, 53-62.

McCarty, J., \& Shrum, L. (2001). The influence of individualism, collectivism and locus of control on environmental beliefs and behaviour. Journal of Public Policy \& Marketing, 21, 93-104.

Melillo, W., \& Miller, S. (2006). Companies find it's not easy marketing green. Brandweek, 47, 8 .

Menon, A. Bharadwaj, S.G., Adidam, P.T., \& Edison, S.W. (1999). Antecedents and consequences of marketing strategy making: A model and a test. Journal of Marketing, 63, 1840.

Menon, A., \& Menon, A. (1997). Enviropreunerial marketing strategy: The emergence of corporate environmentalism as marketing strategy. Journal of Marketing, 61, 51-67.

Minton, A.P., \& Rose, R.L. (1996). The effects of environmental concern on environmentally friendly consumer behavior: An exploratory study. Journal of Business Research, 40, 37-48.

Mostafa, M.M. (2007). A hierarchical analysis of the green consciousness of the Egyptian consumer. Psychology \& Marketig, 24, 445-473.

Myers, M.B., Daugherty, P.J., \& Autry, C.W. (2000). The effectiveness of automatic inventory replenishment in supply chain operations: Antecedents and outcomes. Journal of Retailing, 76, 455-481.

Newell, S.J., Goldsmith, R.E., \& Banzhaf, E.J. (1998). The effect of misleading environmental claims on consumer perceptions of advertisements. Journal of Marketing Theory and Practice, $6,48-61$.

Nibset, E.K., Zelenski, J.M., \& Murphy, S.A. (2010). Happiness is in our nature: Exploring nature relatedness as a contributor to subjective well-being. Journal of Happiness Studies, forthcoming.

Nigbur, D., Lyons, E., \& Uzzell, D. (2010). Attitudes, norms, identity and environmental behaviour: Using an expanded theory of planned behaviour to predict participation in a kerbside recycling programme. British Journal of Sociology, 49, 259-284.

Nunnally, J.C., \& Bernstein, I.H. (1994), Psychometric theory (3rd ed.). New York: McGrawHill.

O’Neill, J., \& Spash, C.L. (2000). Conceptions of value in environmental decision making. Policy Research Brief No.4, Cambridge Research for the Environment.

Olli, E., Grendstad, D., \& Wollebark, D. (2001). Correlates of environmental behaviours: Bringing back social context, Environment and Behavior, 33, 181-208.

Ottman, J.A., Stafford, E.R., \& Hartman, C.L. (2006). Avoiding green marketing myopia: Ways to improve consumer appeal for environmentally preferable products. Environment: Science and Policy for Sustainable Development, 48, 22-36.

Owen, A.L., \& Videras, J. (2006). Civic cooperation, pro-environmental attitudes, and behavioral intentions. Ecological Economics, 58, 814-829.

Paim, L. (1995). Definitions and measurements of wellbeing: A review of literature. Journal of Economic and Social Measurement, 21, 297-309. 
Paladino, A. (2005), Understanding the green consumer: An empirical analysis. Journal of Customer Behaviour, 4, 69-102.

Paladino, A., \& Baggiere, J. (2008). Are we 'green'? An empirical investigation of renewable electricity consumption. European Advances in Consumer Research, 8, 340-341.

Pickett, G.M., Kangun, N., \& Grove, S.J. (1993). Is there a general conserving consumer? A public policy concern. Journal of Public Policy \& Marketing, 12, 234-244.

Porritt, J. (1984). Seeing green: The politics of ecology explained, Oxford: Basil Blackwell.

Prothero, A., McDonagh, P., \& Dobscha, S. (2010), Is green the new black? Reflections on green commodity discourse. Journal of Macromarketing, forthcoming.

Roberts, J.A. (1996). Green consumers in the 1990s: Profile and implications for advertising. Journal of Business Research, 36, 217-231.

Roberts, J.A., \& Bacon, D.R. (1997). Exploring the subtle relationships between environmental concern and ecologically conscious consumer bahavior. Journal of Business Research, 40, 7989.

Rundle-Thiele, S., Paladino, A., \& Apostol, S.A.G.Jr. (2008). Lessons learned from renewable electricity marketing attempts: A case study. Business Horizon, 51, 181-190.

Sarigöllü, E. (2009). A cross-country exploration of environmental attitudes. Environment and Behavior, 41, 365-386.

Schlegelmilch, B.B., Bohlen, G.M., \& Diamantopoulos, A. (1996). The link between green purchasing decisions and measures of environmental consciousness. European Journal of Marketing, 30, 35-55.

Schuhwerk, M.E., \& Lefkoff-Hagius, R. (1995). Green or non-green? Does type of appeal matter when advertising a green product?. Journal of Advertising, 24, 45-54.

Selim, S. (2008). Life satisfaction and happiness in Turkey. Social Indicators Research, 88, 531562.

Shabecoff, P. (1993). A fierce green fire: The American environmental movement. New York, NY: Hill and Wang Publishers.

Sinha, J.B.P., \& Verma, J. (1987). Structure of collectivism. In Ç. Kâgitçibasi (Ed.), Growth and progress in cross-cultural psychology (pp. 123-129). Lisse, The Netherlands: Swets \& Zeitlinger.

Sirgy, M.J. (1998). Materialism and quality of life. Social Indicators Research, 43, 227-260.

Smith, S., \& Paladino, A. (2010). Eating clean and green? Investigating consumer motivations towards the purchase of organic food. Australasian Marketing Journal, 18, 93-104.

Sohr, S. (2001). Eco-activism and well-being: Between flow and burnout. In P. Schmuck and K.M. Sheldon (eds.), Life goals and well-being: Towards a positive psychology of human striving (202-215). Seattle, WA: Hogrefe and Huber.

Solomon, M., Bamossy, G., Askegaard, S., \& Hogg, M. (2010). Consumer behavior: A European perspective ( $4^{\text {th }}$ Edition). Essex: Pearson Education Limited

Sparks, J.R., \& Merenski, J.P. (2000). Recognition-based measures of ethical sensitivity and rformulated cognitive moral development: An examination and evidence of nomological validity. Teaching Business Ethics, 4, 359-377.

Spash, C.L. (1997). Ethics and environmental attitudes with implications for economic valuation. Journal of Environmental Management, 50, 403-416.

Steg, L., Dreijerink, L., \& Abrahamse, W. (2005). Factors influencing the acceptability of energy policies: A test of VBN theory. Journal of Environmental Psychology, 25, 415-425.

Stern, P.C. (2000). Toward a coherent theory of environmentally significant behaviour. Journal of Social Issues, 56, 407-424. 
Stern, P.C., Dietz, T., \& Guagnano, G.A. (1995). The new ecological paradigm in socialpsychological context. Environment and Behavior, 27, 723-743.

Straughan, R.D., \& Roberts, J.A. (1999). Environmental segmentation alternatives: A look at green consumer behaviour in the new millennium. Journal of Consumer Marketing, 16, 558575.

Thøgersen, J., \& Crompton, T. (2009). Simple and painless? The limitations of spillover in environmental campaigning. Journal of Consumer Policy, 32, 141-163.

Triandis, H.C. (1995). Individualism and collectivism. Boulder, CO: Westview.

Van Liere, K.D., \& Dunlap, R.E. (1980). Environmental concern: Does it make a difference how it's measured?. Environment and Behavior, 13, 651-676.

Walsh, G., Mitchell, V.-W., Jackson, P., \& Beatty, S.E. (2009). Examining the antecedents and consequences of corporate reputation: A customer perspective. British Journal of Management, 20, 187-203. 
Table 1: Descriptive statistics of constructs and items

\begin{tabular}{|c|c|c|}
\hline Construct and items & $\begin{array}{c}\text { Item mean* } \\
\text { (S.D.) }\end{array}$ & $\begin{array}{c}\text { Construct mean* } \\
\text { (S.D.) }\end{array}$ \\
\hline Collectivism (COL) $(\alpha=.91, \rho=.86)-$ Adopted from McCarty and Shrum (2001) & & $5.57(1.16)$ \\
\hline COL1-I work hard for the goals of a group, even if it does not result in personal recognition & $5.36(1.42)$ & \\
\hline COL3-I readily help others in need of help & $5.78(1.26)$ & \\
\hline COL4-I do what is good for most of the people in the group, even if it means that I will receive less & $5.36(1.39)$ & \\
\hline COL5-I often share with others items and moments & $5.67(1.40)$ & \\
\hline Long-Term Orientation (LTO) $(\alpha=.78, \rho=.72)-$ Adopted from Hofstede (1980) & & $5.53(1.11)$ \\
\hline LTO1-I always respect others and treat them as they would like to be treated & $5.50(1.35)$ & \\
\hline LTO2-I have a duty to uphold the values and reputation of my family & $5.65(1.32)$ & \\
\hline LTO3-I show respect for traditions & $5.43(1.33)$ & \\
\hline Political Action (PAC) $(\alpha=.87, \rho=.80)-$ Adopted from Bohlen et al . (1993) & & $3.57(1.39)$ \\
\hline PAC1-Often I intervene with the media about societal issues & $3.42(1.61)$ & \\
\hline PAC2-I support political pressure groups/parties in their societal efforts & $3.63(1.63)$ & \\
\hline PAC3-I lobby my political representatives about societal issues & $3.27(1.61)$ & \\
\hline PAC4-I boycott companies that are irresponsible to the society & $3.95(1.73)$ & \\
\hline LIB1-The profits of the big companies should be controlled by the government & $5.51(1.48)$ & \\
\hline LIB2-I support a motional health insurance program covering man and women of all ages & $5.94(1.42)$ & \\
\hline LIB3-If unemployment is high, the government should spend to create jobs & $5.83(1.32)$ & \\
\hline LIB4-I am for revising the tax structure so that the burden falls more heavily on people with large income & $5.70(1.54)$ & \\
\hline Deontology (DEO) $(\alpha=.91, \rho=.87)-$ Adopted from Chan et al. $(2008)$ & & $4.85(1.31)$ \\
\hline DEO1-I am interested in conserving the natural resources & $4.73(1.55)$ & \\
\hline DEO2-I reduce unnecessary waste & $4.84(1.51)$ & \\
\hline DEO3-I try to create and provide living environment for future generations & $4.91(1.46)$ & \\
\hline DEO4-I am concerned about the environment for my future personal convenience & $4.94(1.40)$ & \\
\hline Law Obedience $(\mathrm{LOB})(\alpha=.87, \rho=.81)-$ Adopted from Gaski (1999) & & $5.07(1.26)$ \\
\hline LOB1-I try to avoid committing briberies in my transactions & $5.24(1.48)$ & \\
\hline LOB2-I show respect to the laws of my country and especially those for the environment & $5.19(1.41)$ & \\
\hline LOB3-I abide the safety law for the environment of my country & $5.09(1.45)$ & \\
\hline LOB4-I try to avoid companies that use misleading environmental practices & $4.75(1.56)$ & \\
\hline Inward Environmental Attitude (IEA) $(\alpha=.85, \rho=.79)-$ Adopted from Kilbourne and Pickett (2007) & & $4.72(1.28)$ \\
\hline IEA1-I am very concerned about the environment & $4.98(1.45)$ & \\
\hline IEA4-I have asked my family to recycle some of the things we use & $4.85(1.65)$ & \\
\hline Outward Environmental Attitude (OEA) $(\alpha=.89, \rho=.83)-$ Adopted from Kilbourne and Pickett (2007) & & $5.11(1.31)$ \\
\hline OEA1-Major political change is necessary to protect the natural environment & $4.87(1.49)$ & \\
\hline OEA2-Anti-pollution laws should be enforced more strongly & $5.17(1.49)$ & \\
\hline OEA3-Major social changes are necessary to protect the natural environment & $4.93(1.56)$ & \\
\hline OEA4-Humans are severely abusing the environment & $5.47(1.48)$ & \\
\hline Green Purchasing Behaviour (PUB) $(\alpha=.91, \rho=.85)-$ Adopted from Kilbourne and Pickett (2007) & & $4.59(1.39)$ \\
\hline PUB1-I buy environmental-friendly products, whenever possible & $4.88(1.56)$ & \\
\hline PUB2-I buy organic food, whenever possible & $3.98(1.62)$ & \\
\hline PUB3-I use products made from recycled materials, whenever possible & $4.57(1.61)$ & \\
\hline PUB4-I reduce household waste, whenever possible & $4.69(1.61)$ & \\
\hline PUB5-I recycle household waste, whenever possible & $4.84(1.71)$ & \\
\hline General Environmental Behaviour (ENB) $(\alpha=.84, \rho=.78)-$ Adopted from Kilbourne and Pickett (2007) & & $3.56(1.51)$ \\
\hline ENB1-I am a member of an environmental organisation & $2.84(2.01)$ & \\
\hline ENB2-I contribute money, whenever possible, to environmental organisations & $3.63(1.67)$ & \\
\hline ENB3-I buy/read magazines and listen/watch news which have environmental issues & $4.24(1.89)$ & \\
\hline ENB4-I contact my political representative about any environmental issues & $3.52(1.79)$ & \\
\hline Product Satisfaction (PRS) $(\alpha=.92, \rho=.87)$ - Adopted from Bodet (2008) & & $4.58(1.39)$ \\
\hline PRS1- I think I did the right thing by deciding to buy ecological products & $4.88(1.58)$ & \\
\hline PRS2-I am satisfied with my decision to buy environmental-friendly products & $4.90(1.61)$ & \\
\hline PRS3-There is a big possibility to start buying organic food & $4.24(1.52)$ & \\
\hline PRS4-Environmental-friendly products match my expectations regarding the ideal product & $4.39(1.55)$ & \\
\hline PRS5-My general experience with eco-friendly products is high & $4.50(1.70)$ & \\
\hline Life satisfaction (LIS) $(\alpha=.85, \rho=.79)-$ Adopted from Light et al. (1985) & & $4.46(1.28)$ \\
\hline LIS1-I expect some pleasant things to happen to me in the future, because of my environmental actions & $4.30(1.60)$ & \\
\hline LIS2-The results of my actions regarding the environment seem better than I thought they would be & $4.18(1.45)$ & \\
\hline LIS3-As I look back in life, I am fairly satisfied about my environmental behaviour & $4.40(1.55)$ & \\
\hline LIS4-My life could be happier than it is now, if I took more actions in preserving the environment & $4.96(1.58)$ & \\
\hline
\end{tabular}

\footnotetext{
${ }^{\mathrm{a}}$ Reverse scored item.
}

*Based on a seven-point scale, ranging from $1=$ strongly disagree to $7=$ strongly agree 
Table 2: Results of the measurement models

\begin{tabular}{|c|c|c|c|}
\hline \multicolumn{2}{|l|}{ Model A } & \multicolumn{2}{|l|}{ Model B } \\
\hline Factor & $\begin{array}{l}\text { Stand. } \\
\text { Loadings }\end{array}$ & Factor & $\begin{array}{l}\text { Stand. } \\
\text { Loadings }\end{array}$ \\
\hline Collectivism (COL) & & Inward Environmental Attitude (IEA) & \\
\hline COL1 & $0.81^{\mathrm{b}}$ & IEA1 & $0.82^{\mathrm{b}}$ \\
\hline COL2 & $0.83(19.00)$ & IEA2 & $0.77(17.11)$ \\
\hline COL3 & $0.87(20.24)$ & IEA3 & $0.70(14.90)$ \\
\hline COL4 & $0.84(19.13)$ & IEA4 & $0.77(17.14)$ \\
\hline COL5 & $0.76(16.67)$ & Outward Environmental Attitude (OEA) & \\
\hline Long-Term Orientation (LTO) & & OEA1 & $0.84^{\mathrm{b}}$ \\
\hline LTO1 & $0.75^{\mathrm{b}}$ & OEA2 & $0.92(23.03)$ \\
\hline LTO2 & $0.78(14.41)$ & OEA3 & $0.87(21.44)$ \\
\hline LTO3 & $0.68(12.70)$ & OEA4 & $0.68(14.67)$ \\
\hline Political Action (PAC) & & Green Purchasing Behaviour (PUB) & \\
\hline PAC1 & $0.77^{\mathrm{b}}$ & PUB1 & $0.83^{\mathrm{b}}$ \\
\hline PAC2 & $0.85(16.78)$ & PUB2 & $0.78(18.02)$ \\
\hline PAC3 & $0.83(16.53)$ & PUB3 & $0.83(19.71)$ \\
\hline PAC4 & $0.72(14.11)$ & PUB4 & $0.82(19.36)$ \\
\hline Liberalism (LIB) & & PUB5 & $0.81(18.98)$ \\
\hline LIB1 & $0.64^{\mathrm{b}}$ & General Environmental Behaviour (ENB) & \\
\hline LIB2 & $0.82(13.16)$ & ENB1 & $0.63^{\mathrm{b}}$ \\
\hline LIB3 & $0.87(13.63)$ & ENB2 & $0.82(12.85)$ \\
\hline LIB4 & $0.76(12.48)$ & ENB3 & $0.83(12.91)$ \\
\hline Deontology (DEO) & & ENB4 & $0.74(11.96)$ \\
\hline DEO1 & $0.78^{\mathrm{b}}$ & Product Satisfaction (PRS) & \\
\hline $\mathrm{DEO} 2$ & $0.85(18.30)$ & PRS1 & $0.85^{\mathrm{b}}$ \\
\hline DEO3 & $0.88(19.15)$ & PRS2 & $0.88(22.64)$ \\
\hline DEO4 & $0.87(18.96)$ & PRS3 & $0.81(19.62)$ \\
\hline Law Obedience (LOB) & & PRS4 & $0.83(20.65)$ \\
\hline LOB1 & $0.75^{b}$ & PRS5 & $0.82(19.89)$ \\
\hline LOB2 & $0.89(18.19)$ & Life Satisfaction (LIS) & \\
\hline LOB3 & $0.88(17.99)$ & LIS1 & $0.80^{\mathrm{b}}$ \\
\hline LOB4 & $0.66(13.12)$ & LIS2 & $0.76(15.57)$ \\
\hline & & LIS3 & $0.77(15.82)$ \\
\hline & & LIS4 & $0.74(15.17)$ \\
\hline Goodness-of-Fit Statistics: & & Goodness-of-Fit Statistics: & \\
\hline$\chi_{(237)}^{2}=650.92, p<.001$ & & $\chi_{(284)}^{2}=944.52, p<.001$ & \\
\hline $\begin{array}{l}\mathrm{NFI}=0.96 ; \mathrm{NNFI}=0.97 ; \mathrm{CFI}=0.98 ; \\
\text { RMSEA }=0.06\end{array}$ & & $\mathrm{NFI}=0.97 ; \mathrm{NNFI}=0.98 ; \mathrm{CFI}=0.98 ;$ & \\
\hline RMSEA $=0.06$ & & RMSEA $=0.07$ & \\
\hline
\end{tabular}


Table 3: Correlation matrix

\begin{tabular}{|c|c|c|c|c|c|c|c|c|c|c|c|c|}
\hline Variable & 1. & 2. & 3. & 4. & 5. & 6. & 7. & 8. & 9. & 10. & 11. & 12. \\
\hline 1. Collectivism & 1 & & & & & & & & & & & \\
\hline 2. Long-term Orientation & .63 & 1 & & & & & & & & & & \\
\hline 3. Political Action & .31 & .17 & 1 & & & & & & & & & \\
\hline 4. Liberalism & .55 & .56 & .16 & 1 & & & & & & & & \\
\hline 5. Deontology & .53 & .54 & .42 & .37 & 1 & & & & & & & \\
\hline 6. Law Obedience & .55 & .59 & .34 & .45 & .73 & 1 & & & & & & \\
\hline 7. Inward Environmental Attitude & .55 & .46 & .45 & .35 & .81 & .70 & 1 & & & & & \\
\hline 8. Outward Environmental Attitude & .53 & .60 & .20 & .39 & .66 & .69 & .65 & 1 & & & & \\
\hline 9. Green Purchasing Behaviour & .50 & .38 & .50 & .31 & .79 & .60 & .79 & .55 & 1 & & & \\
\hline 10. General Environmental Behaviour & .33 & .17 & .67 & .18 & .53 & .40 & .60 & .30 & .66 & 1 & & \\
\hline 11. Product Satisfaction & .48 & .41 & .53 & .32 & .73 & .61 & .72 & .60 & .80 & .69 & 1 & \\
\hline 12. Life Satisfaction & .44 & .37 & .45 & .32 & .67 & .58 & .69 & .52 & .68 & .59 & .73 & 1 \\
\hline
\end{tabular}

Note: Correlations greater than $| \pm 0.11|$ are significant at the .01 level. Correlations greater than $| \pm 0.09|$ are significant at the .05 level. 
Table 4: Results of the structural model

\begin{tabular}{llccc}
\hline $\mathbf{H}$ & Hypothesized association & $\begin{array}{c}\text { Standard. } \\
\text { estimate }\end{array}$ & $\begin{array}{c}\boldsymbol{t} \text { - } \\
\text { value }\end{array}$ & $\begin{array}{c}\boldsymbol{p} \text { - } \\
\text { value }\end{array}$ \\
\hline $\mathrm{H}_{1 \mathrm{a}}$ & Collectivism $\rightarrow$ Inward Environmental Attitude & 0.21 & 6.70 & $\mathbf{. 0 0}$ \\
$\mathrm{H}_{1 \mathrm{~b}}$ & Collectivism $\rightarrow$ Outward Environmental Attitude & 0.17 & 4.01 & $\mathbf{. 0 0}$ \\
$\mathrm{H}_{2 \mathrm{a}}$ & Long-Term Orientation $\rightarrow$ Inward Environmental Attitude & -0.17 & -5.33 & $\mathbf{. 0 0}$ \\
$\mathrm{H}_{2 \mathrm{~b}}$ & Long-Term Orientation $\rightarrow$ Outward Environmental Attitude & 0.11 & 2.58 & $\mathbf{. 0 1}$ \\
$\mathrm{H}_{3 \mathrm{a}}$ & Political Action $\rightarrow$ Inward Environmental Attitude & 0.18 & 5.83 & $\mathbf{. 0 0}$ \\
$\mathrm{H}_{3 \mathrm{~b}}$ & Political Action $\rightarrow$ Outward Environmental Attitude & 0.09 & 2.08 & $\mathbf{. 0 4}$ \\
$\mathrm{H}_{4 \mathrm{a}}$ & Liberalism $\rightarrow$ Inward Environmental Attitude. & -0.03 & -1.01 & .31 \\
$\mathrm{H}_{4 b}$ & Liberalism $\rightarrow$ Outward Environmental Attitude. & -0.03 & -0.65 & .52 \\
$\mathrm{H}_{5 \mathrm{a}}$ & Deontology $\rightarrow$ Inward Environmental Attitude & 0.88 & 16.22 & $\mathbf{. 0 0}$ \\
$\mathrm{H}_{5 \mathrm{~b}}$ & Deontology $\rightarrow$ Outward Environmental Attitude & 0.46 & 9.47 & $\mathbf{. 0 0}$ \\
$\mathrm{H}_{6 \mathrm{a}}$ & Law Obedience $\rightarrow$ Inward Environmental Attitude & 0.18 & 5.90 & $\mathbf{. 0 0}$ \\
$\mathrm{H}_{6 \mathrm{~b}}$ & Law Obedience $\rightarrow$ Outward Environmental Attitude & 0.53 & 10.05 & $\mathbf{. 0 0}$ \\
$\mathrm{H}_{7}$ & Inward Environmental Attitude $\rightarrow$ Green Purchasing Behaviour & 0.90 & 15.83 & $\mathbf{. 0 0}$ \\
$\mathrm{H}_{8}$ & Outward Environmental Attitude $\rightarrow$ General Environmental Behaviour & 0.39 & 6.44 & $\mathbf{. 0 0}$ \\
$\mathrm{H}_{9}$ & Green Purchasing Behaviour $\rightarrow$ Product Satisfaction & 0.86 & 16.17 & $\mathbf{. 0 0}$ \\
$\mathrm{H}_{10}$ & General Environmental Behaviour $\rightarrow$ Life Satisfaction & 0.73 & 10.21 & $\mathbf{. 0 0}$
\end{tabular}

Goodness-of-Fit Statistics: Chi-square $\left(\chi^{2}\right)=4965.76, \mathrm{p}=.000 ; d f=1159$; Normed Fit Index (NFI) $=0.95$; Non-Normed Fit Index $(\mathrm{NNFI})=0.96$; Comparative Fit Index $(\mathrm{CFI})=0.96$; Root Mean Squared Error of Approximation $(\mathrm{RMSEA})=0.08$ 


\begin{abstract}
About the authors
Leonidas C. Leonidou is a Professor of Marketing at the School of Economics and Management of the University of Cyprus. He has a MSc and $\mathrm{PhD}$ from the University of Bath. His current research interests are in the areas of international marketing/purchasing, relationship marketing, strategic marketing, and marketing in emerging economies. He has published extensively in these fields and his articles appeared in various journals, such as the European Journal of Marketing, Industrial Marketing Management, Journal of the Academy of Marketing Science, Journal of Business Research, Journal of International Business Studies, Journal of International Marketing, and Journal of World Business.
\end{abstract}
T: +35722892483
F: +35722892481
E: leonidas@ucy.ac.cy

Constantinos N. Leonidou is a Lecturer in Marketing at Leeds University Business School, University of Leeds, UK. He holds an MBA from Cardiff University and has a PhD from the University of Leeds. His main research interests focus on sustainability, international marketing, consumer behaviour, and advertising. His research has appeared in various journals, such as the European Journal of Marketing, Industrial Marketing Management, Journal of International Marketing, and Journal of Marketing Management.

Corresponding author: Dr. Constantinos N. Leonidou, Lecturer in Marketing, Leeds University Business School, University of Leeds, Maurice Keyworth Building, Leeds, LS2 9JT, United Kingdom.
T: +44 (0) 1133436855
F: +44 (0) 1133434885
E: C.Leonidou@leeds.ac.uk

Olga Kvasova is a $\mathrm{PhD}$ candidate in marketing at Lulea University of Technology, Sweden. Her research interests are: marketing and sales management, international marketing, trust and competitive strategy.

E: olgakvasova@list.ru 